\title{
1 Measurement of Light absorbing particles in surface snow of 2 central and western Himalayan glaciers: spatial variability, 3 radiative impacts, and potential source regions
}

4

5
Chaman Gul ${ }^{1,2,3,4}$, Shichang Kang ${ }^{1,4}$, Siva Praveen Puppala ${ }^{2}$, Xiaokang $\mathrm{Wu}^{5}$, Cenlin $\mathrm{He}^{6}$, Yangyang Xu ${ }^{5}$, Inka Koch ${ }^{1}$, Sher Muhammad ${ }^{1}$, Rajesh Kumar ${ }^{6}$, Getachew Dubache ${ }^{3}$

${ }^{1}$ State Key Laboratory of Cryosphere Science, Northwest Institute of Eco-Environment and Resources, Chinese Academy of Sciences, Lanzhou 73000, China

${ }^{2}$ International Centre for Integrated Mountain Development (ICIMOD), G.P.O. Box 3226, Kathmandu, Nepal

${ }^{3}$ Reading Academy, Nanjing University of Information Sciences and Technology 219 Ningliu Road, Nanjing, Jiangsu, 210044 China.

${ }^{4}$ University of Chinese Academy of Sciences, Beijing, China

${ }^{5}$ Department of Atmospheric Sciences, Texas A\&M University, College Station, TX 77843, USA

${ }^{6}$ Research Applications Laboratory, National Center for Atmospheric Research, Boulder, CO 80301, USA

Correspondence: Siva Praveen Puppala (sivapraveen.puppala@icimod.org); 
Abstract. We collected surface snow samples from three different glaciers: Yala, Thana, and Sachin in the central and western Himalayas to understand the spatial variability and radiative impacts of light-absorbing particles. The Yala and Thana glaciers in Nepal and Bhutan, respectively, were selected to represent the central Himalayas. The Sachin glacier in Pakistan was selected to represent the western Himalayas. The samples were collected during the pre-and post-monsoon seasons of the year 2016. The samples were analysed for black carbon (BC) and waterinsoluble organic carbon (OC) through the thermal optical method. The average mass concentrations (BC 2381.39 $\mathrm{ng} \mathrm{g}^{-1}$; OC $3896.00 \mathrm{ng} \mathrm{g}^{-1}$; dust $101.05 \mu \mathrm{g} \mathrm{g}^{-1}$ ) in the western Himalaya (Sachin glacier) were quite higher compared

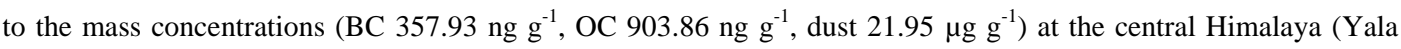
glacier). The difference in mass concentration may be due to the difference in elevation, snow age, local pollution sources, and difference in meteorological conditions. BC in surface snow was also estimated through WRF-Chem simulations at the three glacier sites during the sampling periods. Simulations reasonably capture the spatial and seasonal patterns of the observed BC in snow but with a relatively smaller magnitude. Absolute snow albedo was estimated through the Snow, Ice, and Aerosol Radiation (SNICAR) model. The absolute snow albedo reduction was ranging between $0.48 \%$ (Thana glacier during September) to $24 \%$ (Sachin glacier during May) due to BC and 0.13 $\%$ (Yala glacier during September) to 5\% (Sachin glacier during May) due to dust. The instantaneous radiative forcing due to $\mathrm{BC}$ and dust was estimated in the range of 0 to $96.48 \mathrm{~W} \mathrm{~m}^{-2}$ and 0 to $25 \mathrm{~W} \mathrm{~m}^{-2}$ respectively. The lowest and highest albedo reduction and radiative forcing were observed in central and western Himalayan glaciers, respectively. The potential source regions of the deposited pollutants were inferred using WRF-Chem tagged-tracer simulations. Selected glaciers in the western Himalayas were mostly affected by long-range transport from the Middle East and Central Asia; however, the central Himalayan glaciers were mainly affected by local and South Asia emissions (from Nepal, India, and China) especially during the pre-monsoon season. Overall, South Asia and West Asia were the main contributing source regions of pollutants. 


\section{Introduction}

Black carbon (BC) is a distinct type of carbonaceous material that is formed primarily in flames. BC particles in the atmosphere are generally produced by the incomplete combustion of fossil fuel, biofuel, and biomass. BC is only a minor contributor to aerosol mass but has great climatic interest as a strong absorber of solar radiation (Quinn et al., 2008; Ramanathan and Carmichael, 2008). In addition to warming, BC particles can interact with clouds, changing their microphysical properties, and thus impacting the climate (Wang et al., 2018; Bond et al., 2013; Dong et al., 2021). Besides this, several studies in the past highlighted the role of BC on the cryosphere (Kang et al., 2019, 2020).

The cryosphere is one of the most sensitive indicators of climate change. The temperature rise in cryospheric regions is generally larger than that in other regions on the global scale (Pepin and Lundquist 2008; Kang et al., 2010; You et al., 2021; Huang et al., 2019). BC particles deposit on the glaciers or snow cover surface, decreasing the surface albedo and absorbing more solar radiation (Warren and Brandt, 2008; He et al., 2017) which accelerates snow and ice melt and triggering albedo feedback (Flanner et al., 2009; Hansen and Nazarenko, 2004; Kang et al.,2020). The forcing produced by $\mathrm{BC}$ and other light-absorbing particles (LAPs) further affects the regional climate (Flanner et al., 2009; Xu et al., 2016; Ji et al., 2015) leads to complex responses of the Earth climate system (Hansen et al., 1997). The largest climate forcing from BC in the snow is estimated to occur over the Tibetan Plateau (TP) and Himalayas (Flanner et al., 2009; Ji et al., 2015).

Mountain glaciers are the most important freshwater resources to the lives of arid and semi-arid regions (Hock, 2005, 19; Mayer et al., 2006). The great Himalayas is considered as world's largest freshwater reservoir outside the Polar Regions (Immerzeel et al., 2010; Marcovecchio et al., 2021). The economy and lives of millions of people in the region are influenced by the changes in mountain river discharge downstream of the Himalayas (Vaux et al., 2012). Lack of in-situ data, the low resolution of emission inventory, and coarse model resolutions prevent an accurate evaluation of LAPs impacts on snow albedo and radiative forcing. Many glaciers have retreated in the region due to climate warming (Zhang et al., 2009; Kang et al., 2010; Yao et al., 2019), and possibly due to LAPinduced surface darkening (Flanner et al., 2009; Qian et al., 2011; Kang et al., 2019). Glacier retreat in the TP and the Himalayan region has serious consequences because snow and runoff from this region are sources of major rivers in Asia, and the availability of freshwater resources has profound effects on human health and agriculture (Immerzeel et al., 2010). However, it is still large uncertainties for glacier retreat driven predominately by the deposition of BC and other LAPs (Bolch et al., 2012; Kang et al., 2020).

Snow albedo is an important indicator of surface energy budget over the snow-covered area. Small changes in surface snow albedo can have large impacts on surface warming due to the rapid feedbacks involving changes to sublimation, snow morphology, and melt rates (Bond et al., 2013). The concentration of LAPs in surface snow is a major factor that affects snow albedo. BC and other LAPs present in the snow reduce the albedo in the visible portion of the electromagnetic spectrum (e.g., Warren and Wiscombe, 1980, Flanner et al., 2007). Besides the 
concentration of pollutants deposited on the surface of the snow, multiple other factors, such as solar zenith angle (SZA), snow grain size, snow shape, snow texture, snow density, and snowpack thickness, can also affect snow albedo (He and Flanner, 2020). The radiative transfer model used for the albedo has brought a better understanding of snow optical properties in the shortwave spectrum (He and Flanner, 2020). We estimated the spectral snow albedo using the online Snow, Ice, and Aerosol Radiative (SNICAR) model (Flanner and Zender, 2006). The model was originally developed by Flanner et al., 2007, further updated by He et al. (2018) and Dang et al., (2019), and has been widely used in simulating the impacts of LAPs on snow albedos (Qu et al., 2014).

Here we present the mass concentration of $\mathrm{BC}$, water-insoluble organic carbon (OC), and mineral dust in surface snow from the ablation and accumulation zones of selected glaciers, located in three different countries (Nepal, Bhutan, and Pakistan) on the southern slope of the Himalaya. The Yala and Thana glaciers were selected from the central Himalayas, while the Sachin glacier was selected from the western Himalayas. To reasonably compare the results (mass concentrations, and optical and radiative properties) across the central and western Himalayas, samples were collected on similar dates of the same seasons (pre-monsoon and post-monsoon). We investigate the spatial variability of $\mathrm{BC}, \mathrm{OC}$, and mineral dust concentrations due to differences in the source region, meteorology, deposition, and post-deposition processes. The measured mass concentrations were compared to regional model simulations. The associated changes in surface snow albedo and radiative forcing (RF) by mineral dust and BC in surface snow were estimated using the SNICAR model. We also aim to identify the potential source regions of pollution reaching sampling sites using tracer-tagged model simulations.

\section{Study area and meteorology}

Samples were collected from the Yala glacier $\left(28^{\circ} 14^{\prime} \mathrm{N}, 85^{\circ} 37^{\prime} \mathrm{E}\right)$ in the Langtang valley of Nepal, the Thana glacier $\left(28^{\circ} 01^{\prime} \mathrm{N}, 90^{\circ} 36^{\prime} \mathrm{E}\right)$ in the Chamkhar valley of Bhutan, and the Sachin glacier $\left(35^{\circ} 19^{\prime} \mathrm{N}, 7^{\circ} 45^{\prime} \mathrm{E}\right)$ in northern Pakistan (Table 1). Monthly mean surface air temperature and precipitation (MERRA-2 reanalysis data) over the selected glaciers were analyzed and compared for the western and central Himalayan glaciers from April 2015 to October 2017 (Table 2). Yala Glacier is a plateau-shaped glacier that has an elevation range between 5160 and $5750 \mathrm{~m}$ a.s.l. The length of the Yala glacier is $1.5 \mathrm{~km}$ facing the northwest. The glacier is located away from the residential area and is mostly covered by firm/snow especially during the winter season. Details about the metrological condition at the Yala glacier are available in Mukesh et al., (2019) and Gul et al., (2021). Thana glacier is a gentle slope glacier with slight debris cover and an elevation range between 5250 and $5700 \mathrm{~m}$ a.s.l. The length of the glacier is about $5 \mathrm{~km}$, facing the southwest. The Thana glacier is mostly covered by fresh snow especially during the winter season. The Sachin glacier has a gentle slope with dense debris cover in its ablation area with an altitude range from 3105 to $4976 \mathrm{~m}$ a.s.l. The length of the Sachin glacier is around $8 \mathrm{~km}$ facing northeast. In general, the Sachin, glacier is low elevated and relatively debris-covered glaciers as compared to central Himalayan glaciers (Yala and Thana). Precipitation in central Himalayan glaciers (Yala and Thana) was higher than that of the western Himalayan glacier (Sachin) especially from April to October each year (Table 2). Surface air temperature over the Yala and Sachin glacier was higher than that of the Thana glacier. The geographical location of the selected 
glaciers and snow sampling locations are shown in Fig. 1. Besides the difference in altitude, latitude, and meteorology of the selected glaciers in the central and western Himalayas, there is also a difference in the surface condition shown in supplementary Fig. S1.

\section{Methodologies}

\subsection{Snow sampling and analysis}

Snow samples were collected from the central and western Himalayan glaciers during May, and September 2016. Samples were taken from the surface of the selected glaciers; however, few snow samples were also collected from the surrounding nearby areas of the Yala and Sachin glaciers. The snow density was measured with a small density kit. The snow grain size was measured through a hand lens $(25 \times)$ with an accuracy of $0.02 \mathrm{~mm}$. A detailed description of the sampling procedure is described in Gul et al., 2021. Quartz filters were used to measure the mass concentration of BC, OC, and dust in the collected samples. BC and OC present in snow samples were analyzed by a filter-based thermal-optical analysis method using DRI® Model 2005 (Chow et al., 1993). Filters were analyzed at the State Key Laboratory of Cryosphere Science, Northwest Institute of Eco-Environment and Resources, Chinese Academy of Sciences. Before starting the analysis, a piece of the sampled filters was put in an oven for a few minutes to eliminate the water vapor content and volatile organic compounds. Further detailed information on the instrument and analysis method can be referred to in earlier studies (Gul et al., 2018, 2021).

\subsection{Estimation of snow albedo reduction and radiative forcing}

The online snow simulation model SNICAR (Flanner et al., 2007, http://snow.engin.umich.edu/) was used to estimate snow albedo calculation for the collected samples. The model has been used by multiple studies in the past (e.g., Li et al., 2017; Gul et al., 2018; Zhang et al., 2018 ). Albedo was simulated based on an hourly SZA at the sampling site with an averaged mass concentration of BC, dust, and other input parameters such as snow grain size, snow density, and snow depth from measurements. We computed broadband snow albedo for direct solar incident radiation under the mid-latitude winter clear sky condition, (Supplementary Table S1). Depending on geographical location, 10 to 15 SZAs were used (between $0^{\circ}$ and $90^{\circ}$ ) during instantaneous daytime albedo simulation. Albedo was simulated in four categories: 1- broadband albedo with BC and dust in snow, 2- broadband albedo with BC in snow only, 3- broadband albedo with dust in snow only, and 4- broadband albedo with the absence of BC and dust which was considered as a reference albedo. Radiative implications caused by snow darkening due to BC and dust deposition were investigated using the albedo reduction and the radiative transfer model Santa Barbara DISORT Atmospheric Radiative Transfer (SBDART) (Ricchiazzi et al., 1998). To evaluate the amount of additional solar radiations absorbed by the snow in the presence of $\mathrm{BC}$ and dust, we estimated the mean solar irradiance and its characteristics via SBDART, which has been used in the past (Yang et al., 2015). According to the location of the sampling site, the characteristics of the atmospheric profiles such as water vapor, aerosols, ozone, etc. were set in the model. RF-based on measured BC and dust concentration in our samples were estimated using the following equation. 
where, $\mathrm{R}_{\text {in-short }}$ denotes incident short-wave solar radiation for selected SZA and $\Delta \alpha_{\mathrm{x}}$ denotes the reduction in albedo due to BC, dust, or both, as simulated by the SNICAR model.

\subsection{Potential source region of pollutants}

165

166

167

168

169

170

171

172

173

174

175

176

177

178

179

180

181

182

183

184

185

186

187

188

189

190

191

192

193

194

195

196

Glaciers of the Himalaya Karakoram and Hindukush $(\mathrm{HKH})$ region are located at high altitudes as compared to the sources of the major pollutants. LAPs including BC and dust can transport from urban areas towards glaciated areas (e.g., Yasunari et al., 2009; Kang et al., 2019). Multiple approaches, including climate circulation modeling, combinations of bottom-up inventories, and back air trajectories have been used in the past to determine the possible source regions of pollution in the HKH region. To identify the potential source region of pollution for the central and western Himalayan glaciers, the weather research and forecasting (WRF) model coupled with chemistry (WRFChem version 3.9.1.1) (Grell et al., 2005) tagged-tracer simulations for the selected sites.

WRF-Chem simulations were used to estimate BC mass concentration in surface snow and deposition of BC particles on three selected glaciers (Yala, Thana, and Sachin). We archived the hourly model results for instantaneous BC deposition and concentration in snow. The horizontal grid spacing of the model was $20 \mathrm{~km} \times 20$ $\mathrm{km}$ with 35 vertical levels stretching from the surface up to $50 \mathrm{hPa}(\sim 20 \mathrm{~km})$. The updated Model for OZone And Related chemical Tracers (MOZART) was applied for the gas phase chemistry (Knote et al., 2014) while aerosols in the WRF-Chem were simulated via the Model for Simulating Aerosol Interactions and Chemistry (MOSAIC) (Zaveri et al., 2008). We use the Global Data Assimilation System (GDAS) from the National Center for Environmental Prediction (NCEP) for the meteorological initial and boundary conditions. We used the Fire Inventory from NCAR (FINN), the EDGAR-HTAP, and MEGAN (Model of Emissions of Gases and Aerosols from Nature) for biomass burning emissions, anthropogenic emissions, and for online biogenic emissions, respectively. For chemical boundary conditions, we used the NCAR global CAM-Chem simulation dataset (https://rda.ucar.edu/datasets/ds313.7/). Key meteorological variables such as winds, temperature, and water vapor above the planetary boundary layer (PBL) were nudged every 6 hours towards the NCEP GDAS reanalysis fields to reduce temporal error growth in meteorological variables. We used the Community Land Model (CLM) scheme for the land component in WRF-Chem. The CLM model can simulate BC concentration in snowpack and its effects on snow albedo (Flanner et al., 2007). We used online coupled BC deposition fluxes from the atmosphere component of WRF-Chem with the CLM model following Zhao et al. (2014). We also implemented a tagged-tracer method (Kumar et al., 2015) to track anthropogenic BC emissions from 10 different Asian countries surrounding the TP areas, as well as BC emissions from Asian biomass burning and the domain boundary (i.e., areas outside Asia). The tracked 10 anthropogenic emission source regions include China, India, Nepal, Pakistan, Afghanistan, Bhutan, Bangladesh, Myanmar, Southeast Asia, and the rest of Asia. The aim of the model simulation was to estimate the $\mathrm{BC}$ mass concentration in surface snow, deposition of $\mathrm{BC}$ particles, and the source contribution to BC deposition on snow. 


\section{Results and discussions}

\subsection{Concentrations of light-absorbing particles in surface snow}

The average mass concentration of LAPs in surface snow of the Yala glacier was $357.93 \mathrm{ng} \mathrm{g}^{-1}$ for BC, $903.86 \mathrm{ng} \mathrm{g}^{-1}$ for $\mathrm{OC}$, and $21.95 \mu \mathrm{g} \mathrm{g}^{-1}$ for dust in spring (May) and was relatively lower concentrations of $68.97 \mathrm{ng} \mathrm{g}^{-1}$ for BC, $177.50 \mathrm{ng} \mathrm{g}^{-1}$ for OC and $4.3 \mathrm{ng} \mathrm{g}^{-1}$ for dust during autumn (September). These mass concentrations of BC and OC in surface snow were comparable to the study result conducted on the Yala glacier in May 2017 (Gul et al., 2021). High LAP concentration in the pre-monsoon is due to a seasonally high Indian subcontinent emission (Kang et al., 2019; Gul et al., 2021); Lau et al., (2010) also confirmed that aerosols from biofuel and biomass burning rapidly build up over Indo-Gangetic Plains (IGP) and East Asia during pre-monsoon season and move towards the study site. The average surface concentrations of BC, OC, and dust in the Thana glacier samples during the autumn season were $39.39 \mathrm{ng} \mathrm{g}^{-1}, 115 \mathrm{ng} \mathrm{g}^{-1}$ and $34.63 \mu \mathrm{g} \mathrm{g}^{-1}$, respectively. Possible reasons for the lowest concentration at the Thana glacier may be due to the relatively high elevation of sampling location and relatively fresh snow. A strong effect of LAPs (BC and dust) has been observed at lower elevations in comparison to higher elevations (Li et al., 2017). The average concentration of $\mathrm{BC}, \mathrm{OC}$, and dust measured in the selected western Himalayan glacier (Sachin) during May were $2381.39 \mathrm{ng} \mathrm{g}^{-1}, 3896 \mathrm{ng} \mathrm{g}^{-1}$ and $101 \mu \mathrm{g} \mathrm{g}^{-1}$, respectively, and were relatively higher during October with values of $5314 \mathrm{ng} \mathrm{g}^{-1}$ for $\mathrm{BC}$, and $546 \mathrm{\mu g} \mathrm{g}^{-1}$ for dust (Gul et al., 2018). The observed average mass concentrations in the western Himalayas were higher than those in the central Himalayas. The BC mass concentration difference might be due to the difference in snow type, precipitation rate, and local emission, the elevation of sampling sites, meteorology, and BC deposition over the glacier surfaces. Post dry deposition of LAPs over the surface of the snow was an important factor. Snow samples collected from the western side of the Himalayas were aged as compared to the central side; post-deposition ion (or enrichment) of LAPs over the snow surface increased the concentration in the snow (Kang et al., 2019). The majority of the samples from the western Himalayan side were from ablation zones of the glacier, where concentrations of LAPs are higher as compared to the accumulation zone of the glacier. Li et al., (2017) showed a strong negative relationship between the elevation of glacier sampling locations and the concentration of LAPs. Therefore strong melting of surface snow and ice in the glacier ablation zone could lead to BC enrichment which causes high BC concentrations ( $\mathrm{Li}$ et al., 2017). In the case of western Himalayan glaciers sites, snow samples were collected long after the snowfall and the concentration of pollutants would also have increased in the surface snow due to dry deposition. The surface concentrations of the individual samples collected from the Yala, Thana, and Sachin glaciers during May and September 2016 are shown in Fig. 2, and Table S2. BC and OC concentration on our selected glaciers with a comparison to other glaciers of TP and the surrounding region are shown in Fig. 4 and Table S3. It was observed that the concentration of BC, OC, and dust in the central Himalayan glaciers (Yala and Thana) were comparable to other reported results. In the past, similarly high concentrations were reported in the region (Xu et al., 2012) such as Tien Shan Mountains (Li et al., 2016), Northeast of the TP (Wang et al., 2016), Northern China (Zhang et al., 2016) Southeastern TP, western Tien Shan and Central Asia (Zhang et al., 2017). 
233 The yellow boxes of Fig. 2 show the WRF-Chem modeled BC concentrations in surface snow at the three measurement glacier sites during the measurement periods. Compared to the observations red boxes in Fig. 2, model results reasonably capture the spatial and seasonal patterns and variables of the observed $\mathrm{BC}$ in the snow with a relatively smaller magnitude. The modeled variation at the Sachin site during the October sampling periods is much larger than the observations (Gul et al., 208). The discrepancies between model results and observations are due to model uncertainties from (1) the relatively coarse grid spacing that may not capture the transport over the complex TP terrain, (2) the underestimated anthropogenic emissions that are not representative for the measurement periods, and (3) deficiencies in model physical parameterizations that affects BC transport and deposition. We also note that the observed variation at each site shown in Fig. 2 includes both the temporal and subgrid variabilities derived from multiple sampling locations surrounding each site (Fig. 1). In contrast, all the measurement locations at each particular glacier site are located within a single model grid. As a result, the model is unable to resolve this subgrid information and hence only includes the temporal variability for each selected site.

\subsection{Surface snow albedo and radiative forcing}

The minimum daytimes absolute albedo reduction due to combined $\mathrm{BC}$ and dust, $\mathrm{BC}$ only and dust only were in the range (1.03-13.44\%), (0.48-12.42\%) and (0.12-2.12\%), respectively. The maximum daytime albedo reduction due to combined BC and dust, BC only and dust only was in the range (1.98-24.97\%), (1.05-24\%), and (0.25-4.8\%) respectively. The lowest and highest contributions in albedo reduction were observed in the central Himalayas (September) and the western Himalayas (May) respectively. Snow albedo reduction (\%) derived from samples collected from the Yala glacier (during May 2016) and the Thana glacier (during September 2016) were in the range of (0.13-3.82\%) and (0.90-1.99\%), respectively. A significant difference in daytime albedo reduction between the western and central Himalayas was mainly due to the difference in mass concentrations of pollutants and snow age. The pollutant concentrations in the western Himalayan samples (Sachin glacier) were higher, resulting in higher albedo reduction as compared to the central Himalayan (Yala and Thana glaciers) samples. The average elevation difference between central and western sampling sites was greater than 1000 meters, where a high concentration of pollution is expected at the low elevated glacier of the western side as compared to the central side of the Himalaya. Snow samples collected on the central side of the Himalayas (Yala glacier) were much fresher as compared to the samples collected from the western side (Sachin glacier). Dust and other pollutants were visible over the surface of the Sachin glacier (Fig. S1). Aged snow had increased density, enlarged grain size, and increased concentration of $\mathrm{BC}$ and dust particles due to dry deposition on the snow surface. In the case of all sampling sites impact of BC on snow albedo reduction was greater than the impact of dust except the Thana glacier where the impact of dust was higher than that of BC (Fig. 4a). This may be due to a different dust type in Thana samples. Daytime snow albedo reductions (\%) due to $\mathrm{BC}$ only, dust only, and both $\mathrm{BC}$ and dust are given in Fig. $4 \mathrm{a}$.

The daytime instantaneous RF ( $\mathrm{W} \mathrm{m}^{-2}$ ) ranged from (0.076 to 39.65) for the Yala glacier during May 2016, 0.006 to 18.26 for the Yala glacier during September 2016, 0.0 to 11.48 for the Thana glacier during September 2016, and 0.03 to 96.48 for the Sachin glacier during May 2016. RF for the western Himalayas (Sachin glacier) was quite high 
as compared to the central Himalayan glaciers (Yala and Thana glaciers). The radiative effect on the Sachin glacier was much more than that of other selected glaciers mainly due to low albedo and increased temperature. Zhang et al. (2017) reported that a reduction in albedo by 9 to $64 \%$ can increase the instantaneous RF by as much as $24.05-$ $323.18 \mathrm{~W} \mathrm{~m}^{-2}$. In the case of all sampling sites impact of BC on RF was greater than the impact of dust except the Thana glacier where the impact of dust was higher than that of $\mathrm{BC}$ (Fig. 4b). Therefore, BC can be a major responsible pollutant in the snow to reduce albedo and increase warming in the selected glaciers. BC was the dominant factor in snow melting in the Yala and Sachin glaciers; however, dust was the dominant factor in Thana glacier samples. According to (Kaspari et al., 2014), RF caused by mineral dust was greater than that of dust. The BC and dust had low importance for RF in fresh snow (central Himalaya - Thana glacier) as compared to aged snow (western Himalaya - Sachin glacier). In the northern TP, BC played important role in RF (Li et al., 2016a), while in the central TP and Himalayas dust was more important than BC (Kaspari et al., 2014). The average instantaneous RF caused by the combined contribution of $\mathrm{BC}$ and dust $(\mathrm{BC}+$ dust $)$, only $\mathrm{BC}$, and only dust is shown in Fig. $4 \mathrm{~b}$ as a function of surface snow types. Variation in the RF and albedo change for a particular pollutant type was due to variation in SZA.

\section{Potential source regions of pollutants}

Figure 5 shows the contributions of different BC emission sources to the BC in snow from WRF-Chem taggedtracer simulations. For the Yala site, it is dominated (>50\%) by anthropogenic emissions from India and Nepal for both May and October, while the biomass burning contribution (>20\%) increases largely in May primarily due to the spring burning activities in northern India (Kumar et al., 2011). In September, China's contribution also increases to $>20 \%$ at Yala. For the Thana site, it is dominated (>60\%) by anthropogenic emissions from China and India in September, while anthropogenic emissions from Bhutan and Myanmar also contribute about 10\%, respectively. The Sachin site is predominantly affected by anthropogenic emissions from India and Pakistan (total contribution $>80 \%$ ), while the spring biomass burning only contributes to $\sim 10 \%$ in May. Overall, the source contributions show large variation depending on the site locations and sampling seasons, but with a consistent India contribution of 20$40 \%$ across all the sites and seasons.

\section{Discussion on uncertainty in measurements, albedo, and potential source identification of pollutants}

The possible uncertainties in the present research were related to measurements, sampling, analysis, albedo, and RF estimation. A sampling at remote rural sites, sample preservation, filtration, and transport can modify the results if proper standard protocols were not followed. During laboratory analysis via thermal optical techniques, several uncertainties may be related to separating OC from BC in the sample (Gul et al., 2021). The level of generated uncertainty depended on temperature protocol, sample type (residential cookstoves, diesel exhaust, rural aerosols, and urban aerosols), the amount of dust loading on the filter, and the analysis method. The overall accuracy in the measurement of $\mathrm{OC}, \mathrm{BC}$, and total carbon concentrations was estimated considering the mass contributions from field blanks and the analytical accuracy of concentration measurements. The uncertainty of the OC and BC mass concentrations was extracted through the standard deviation of the field blanks (li et al., 2021). OC in snow can 
produce minor warming (Yasunari et al., 2015), but in this research albedo reduction from OC was not quantified. In albedo simulation and RF estimations, snow grain size and texture can produce large uncertainty. We measured/considered the physical grain size in this research which is not the same as the effects than optical grain size. Optical grain size defines the amount of solar radiation absorbed/scattered by the snow. We assumed a spherical shape for the snow grains which may affect the results because the albedo of non-spherical grains is higher than the albedo of spherical grains (Dang et al., 2016; He et al., 2018). The contribution of pollutants generated from local sources can be important (e.g., Li et al., 2021), which however was not included in the global emission inventories; we were unable to capture emissions at the local scale. Therefore contributions of local sources may be underestimated by coarse-resolution models. High-resolution models and emission inventories at the local scale are required to capture local emissions.

\section{Conclusions}

The average mass concentration of LAPs in the samples collected from the Sachin, Yala, and Thana glaciers were in the range (835.324 $\mathrm{ng} \mathrm{g}^{-1}$ to $3545.35 \mathrm{ng} \mathrm{g}^{-1}$ for $\mathrm{BC}$ and $35.24 \mu \mathrm{g} \mathrm{g}^{-1}$ to $253.52 \mu \mathrm{g} \mathrm{g}^{-1}$ for Dust), (23.16 $\mathrm{ng} \mathrm{g}^{-1}$ to $2529 \mathrm{ng} \mathrm{g}^{-1}$ for $\mathrm{BC}$ and $1.5 \mu \mathrm{g} \mathrm{g}^{-1}$ to $196.5 \mu \mathrm{g} \mathrm{g}^{-1}$ for Dust), and (21 $\mathrm{ng} \mathrm{g}^{-1}$ to $127 \mathrm{ng} \mathrm{g}^{-1}$ for $\mathrm{BC}$ and $1.5 \mu \mathrm{g} \mathrm{g}^{-1}$ to 67 $\mu \mathrm{g} \mathrm{g}{ }^{-1}$ for Dust) respectively. Overall the concentrations of $\mathrm{BC}$ and dust were varied from $21 \mathrm{ng} \mathrm{g}^{-1}$ and $1.5 \mu \mathrm{g} \mathrm{g}^{-1}$ in fresh snow to $3545 \mathrm{ng} \mathrm{g}^{-1}$ and $253 \mu \mathrm{g} \mathrm{g}^{-1}$ in the aged snow, respectively. Mass concentrations of BC, OC, and dust in the samples collected from the western Himalayas was much higher than the average concentration in the central Himalayas mainly due to difference in snow age, elevation, and meteorology. The accumulation area of glaciers (e.g. ice cores and snow pits), where enrichment influences are less marked and measured values are likely to be lower, and high elevation areas, where deposition of pollutants is expected to be lower. Pollutant concentrations were likely underestimated in the earlier studies, particularly when there was strong surface melting. Dust and other pollutants were visible on aged snow surfaces in the western Himalaya, indicating considerable enrichment during snow aging. WRF-Chem modeled BC concentrations in surface snow were almost similar to the observed BC in the snow with a relatively smaller magnitude.

Based on observed pollutants, snow albedo reduction $(\%)$ in the central Himalayas was in the range of $(0.48-3.6 \%$ for BC) and (0.13-1.99\% for Dust), much lower than that of the western Himalayas. BC was the major component responsible for the albedo reduction, and the dust had little effect except in the Thana glacier. In case the of the Thana glacier, the impact of dust was higher than that of BC. The daytime instantaneous radiative forcing $\left(\mathrm{W} \mathrm{m}^{-2}\right)$ ranged from 0.076 to 39.65 (Yala glacier during May 2016), 0.006 to 18.26 (Yala glacier during September 2016), 0.0 to 11.48 (Thana glacier during September 2016), 0.03 to 96.48 (Sachin glacier during May 2016). The average albedo reduction due to the combined effect of dust and BC at the western Himalayan side (Sachin glacier) was 0.372 which was 15 times higher than that of the central Himalayan side (Yala glacier). Similarly, the radiative forcing in the western Himalayas was $\sim 6$ times higher than that of the central Himalayan side. Observation showed that the potential source regions of pollutants for the western and central Himalayas were different. Western Himalayan glaciers were mostly affected by long-range transport via the westerlies; however central Himalayan 
glaciers were affected by relatively local winds from Nepal, Bhutan, India, and China. For the western Himalayan glaciers, the emissions from central Asian and South Asian countries (Particularly Pakistan and India) are more important source regions.

\section{Acknowledgment}

This study was supported by the National Natural Science Foundation of China (41630754), the Chinese Academy of Sciences (XDA20040501, QYZDJ-SSW-DQC039), and the State Key Laboratory of Cryosphere Science (SKLCS-ZZ-2021). This study was also partially supported by the core funds of ICIMOD contributed by the governments Afghanistan, Australia, Austria, Bangladesh, Bhutan, China, India, Myanmar, Nepal, Norway, Pakistan, Sweden, and Switzerland. We thank Arnico Panday, Lubna ayaz and Aditi Mukherji for their useful comments and guidance. We are also grateful to the staff of the National Centre for Hydrology and Meteorology in Bhutan for organizing the Thana Glacier expedition in 2016. We would like to acknowledge high-performance computing support from Cheyenne provided by NCAR's Computational and Information Systems Laboratory, sponsored by the National Science Foundation. NCAR is operated by the University Corporation for Atmospheric Research under the sponsorship of the National Science Foundation.

\section{References}

Bolch, T., Kulkarni, A., Kääb, A., Huggel, C., Paul, F., Cogley, J. G., Frey, H., Kargel, J. S., Fujita, K., Scheel, M., Bajracharya, S., and Stoffel, M.: The State and Fate of Himalayan Glaciers, Science, 336, 310-314, 2012.

Bond, T. C., Doherty, S. J., Fahey, D. W., Forster, P. M., Berntsen, T., DeAngelo, B. J., Flanner, M. G., Ghan, S., Kärcher, B., Koch, D., Kinne, S., Kondo, Y., Quinn, P. K., Sarofim, M. C., Schultz, M. G., Schulz, M., Venkataraman, C., Zhang, H., Zhang, S., Bellouin, N., Guttikunda, S. K., Hopke, P. K., Jacobson, M. Z., Kaiser, J. W., Klimont, Z., Lohmann, U., Schwarz, J. P., Shindell, D., Storelvmo, T., Warren, S. G., and Zender, C. S.: Bounding the role of black carbon in the climate system: A scientific assessment, J. Geophys. Res.-Atmos., 118, 5380-5552, doi:10.1002/jgrd.50171, 2013.

Chow, J. C., Watson, J. G., Pritchett, L. C., Pierson, W. R., Frazier, C. A., and Purcell, R. G.: The DRI thermal/optical reflectance carbon analysis system: description, evaluation, and applications in US air quality studies, Atmos. Environ. A-Gen., 27, 1185-1201, 1993.

Dang, C., Zender, C. S., and Flanner, M. G. (2019), Intercomparison and improvement of twostream shortwave radiative transfer schemes in Earth system models for a unified treatment of cryospheric surfaces, The Cryosphere, 13, 2325-2343, doi:10.5194/tc-13-2325-2019, 2019.

Dang, C., Fu, Q., and Warren, S. G.: Effect of snow grain shape on snow albedo, J. Atmos. Sci., 73, 35733583, https://doi.org/10.1175/JAS-D-15-0276.1, 2016.

Flanner, M. G. and Zender, C. S.: Linking snowpack microphysics and albedo evolution, J. Geophys. Res. Atmos., 111(12), 1-12, doi:10.1029/2005JD006834, 2006.

Flanner, M. G., Zender, C. S., Randerson, J. T. and Rasch, P. J.: Present-day climate forcing and response from black 
carbon in snow, J. Geophys. Res. Atmos., 112(11), 1-17, doi:10.1029/2006JD008003, 2007.

Flanner, M. G., Zender, C. S., Hess, P. G., Mahowald, N. M., Painter, T. H., Ramanathan, V. and Rasch, P. J.: Springtime warming and reduced snow cover from carbonaceous particles, Atmos. Chem. Phys. Discuss., 8(6), 19819-19859, doi:10.5194/acpd-8-19819-2008, 2009.

Grell, G. A., Peckham, S. E., Schmitz, R., McKeen, S. A., Frost, G., Skamarock, W. C., and Eder, B.: Fully coupled “online" chemistry within the WRF model, Atmos. Environ., 39, 6957-6975, 2005.

Gul, C., Puppala, S.P., Kang, S., Adhikary, B., Zhang, Y., Ali, S., Li, Y., Li, X., 2018. Concentrations and source regions of light-absorbing particles in snow/ice in northern Pakistan and their impact on snow albedo. Atmos. Chem. Phys. 18, 4981-5000. https://doi.org/10.5194/acp-18-4981-2018

Gul, C., Mahapatra, P.S., Kang, S., Singh, P.K., Wu, X., He, C., Kumar,R., Rai, M., Xu, Y., Puppala, S.P., Black carbon concentration in the central Himalayas: impacton glacier melt and potential source contribution, Environmental Pollution, https://doi.org/10.1016/j.envpol.2021.116544.

Hansen, J. and Nazarenko, L.: Soot climate forcing via snow and ice albedos, Proc. Natl. Acad. Sci. U. S. A., 101(2), 423-428, doi:10.1073/pnas.2237157100, 2004.

Hansen, J., Sato, M. \& Ruedy, R.: Radiative forcing and climate response, J. Geophys. Res. 102, 6831-6864, doi.org/10.1029/96JD03436,1997

He, C., Flanner, M. G., Chen, F., Barlage, M., Liou, K.-N., Kang, S., Ming, J., and Qian, Y.: Black carbon-induced snow albedo reduction over the Tibetan Plateau: uncertainties from snow grain shape and aerosol-snow mixing state based on an updated SNICAR model, Atmos. Chem. Phys., 18, 11507-11527, https://doi.org/10.5194/acp18-11507-2018, 2018

He, C., \& Flanner, M. (2020). Snow Albedo and Radiative Transfer: Theory, Modeling, and Parameterization. Kokhanovsky A, editor, 67-133.

He, C., Takano, Y., Liou, K. N., Yang, P., Li, Q., \& Chen, F. (2017). Impact of snow grain shape and black carbonsnow internal mixing on snow optical properties: Parameterizations for climate models. Journal of Climate, 30(24), 10019-10036. doi:10.1175/JCLI-D-17-0300.1

Hock R.: Glacier melt: a review of processes and their modelling. Progr. Phys. Geogr., 29(3), 362-391, doi: 10.1191/0309133305pp453ra, 2005.

Hock, R., G. Rasul, C. Adler, B. Cáceres, S. Gruber, Y. Hirabayashi, M. Jackson, A. Kääb, S. Kang, S. Kutuzov, Al. Milner, U. Molau, S. Morin, B. Orlove, and H. Steltzer, 2019: High Mountain Areas. In: IPCC Special Report on the Ocean and Cryosphere in a Changing Climate [H.-O. Pörtner, D.C. Roberts, V. Masson-Delmotte, P. Zhai, M. Tignor, E. Poloczanska, K. Mintenbeck, A. Alegría, M. Nicolai, A. Okem, J. Petzold, B. Rama, N.M. Weyer (eds.)]. In press.

Immerzeel, W. W., van Beek, L. P. H. and Bierkens, M. F. P.: Climate change will affect the Asian water towers., Science, 328(5984), 1382-5, doi:10.1126/science.1183188, 2010.

Ji Z., S. Kang, Z. Cong, Q. Zhang, T. Yao. 2015. Simulation of carbonaceous aerosols over the Third Pole and adjacent regions: distribution, transportation, deposition, and climatic effects. Climate Dynamics, 45(9-10): 2831-2846. https://doi.org/10.1007/s00382-015-2509-1. 
Kang S., Y. Zhang, Y. Qian, H. Wang. 2020. A review of black carbon in snow and ice and its impacts on cryospheric change. Earth-Science Reviews, 210, 103346. https://doi.org/10.1016/j.earscirev.2020.103346.

Kang S., Q. Zhang, Y. Qian, Z. Ji, C. Li, Z. Cong, Y. Zhang, J. Guo, W. Du, J. Huang, Q. You, A. K. Panday, M. Rupakheti, D. Chen, Örjan Gustafsson, M. H. Thiemens, D. Qin. 2019. Linking Atmospheric Pollution to Cryospheric Change in the Third Pole Region: Current Progresses and Future Prospects. National Science Review, 6(4): 796-809. https://doi.org/10.1093/nsr/nwz031.

Kang S., X. Wei, Q. You, Wolfgang-Albert Flügel, Nick Pepin, T. Yao. 2010. Review of climate and cryospheric change in the Tibetan Plateau. Environmental Research Letter, 5(2010) 015101 (8pp). https://doi.org/10.1088/1748-9326/5/1/015101.

Kaspari, S., Painter, T. H., Gysel, M., Skiles, S. M. and Schwikowski, M.: Seasonal and elevational variations of black carbon and dust in snow and ice in the Solu-Khumbu, Nepal and estimated radiative forcings, Atmos. Chem. Phys., 14(15), 8089-8103, doi:10.5194/acp-14-8089-2014, 2014.

Knote, C., Hodzic, A., Jimenez, J. L., Volkamer, R., Orlando, J. J., Baidar, S., Brioude, J., Fast, J., Gentner, D. R., Goldstein, A. H., Hayes, P. L., Knighton, W. B., Oetjen, H., Setyan, A., Stark, H., Thalman, R., Tyndall, G., Washenfelder, R., Waxman, E., and Zhang, Q.: Simulation of semi-explicit mechanisms of SOA formation from glyoxal in aerosol in a 3-D model, Atmos. Chem. Phys., 14, 6213-6239, doi:10.5194/acp-14-6213-2014, 2014.

Kumar, R., Barth, M. C., Nair, V. S., Pfister, G. G., Suresh Babu, S., Satheesh, S. K., Krishna Moorthy, K., Carmichael, G. R., Lu, Z., and Streets, D. G.: Sources of black carbon aerosols in South Asia and surrounding regions during the Integrated Campaign for Aerosols, Gases and Radiation Budget (ICARB), Atmos. Chem. Phys., 15, 5415-5428, https://doi.org/10.5194/acp-15-5415-2015, 2015.

Kumar, R., Naja, M., Satheesh, S. K., Ojha, N., Joshi, H., Sarangi, T., Pant, P., Dumka, U. C., Hegde, P., and Venkataramani, S. (2011), Influences of the springtime northern Indian biomass burning over the central Himalayas, J. Geophys. Res., 116, D19302, doi:10.1029/2010JD015509.

Lau, K. M., Kim, M. K., and Kim, K. M.: Enhanced surface warming and snow melt in the Himalayas and Tibetan Plateau induced by the EHP effect, Environ. Res. Lett., 5, 025204, doi:10.1088/1748-9326/5/2/025204, 2010.

Li, C., Yan, F., Kang, S., Yan, C., Hu, Z., Chen, P., ... \& Stubbins, A. (2021). Carbonaceous matter in the atmosphere and glaciers of the Himalayas and the Tibetan plateau: An investigative review. Environment International, 146, 106281

Li, X., Kang, S., He, X., Qu, B., Tripathee, L., Jing, Z., Paudyal, R., Li, Y., Zhang, Y., Yan, F., Li, G. and Li, C.: Light-absorbing impurities accelerate glacier melt in the Central Tibetan Plateau, Sci. Total Environ., doi:10.1016/j.scitotenv.2017.02.169, 2017.

Li, Yang, S. Kang, Xuelei Zhang, Jizu Chen, Julia Schmale, Xiaofei Li, Yulan Zhang, Hewen Niu, Zhongqin Li, Xiang Qin, Xiaobo He, Wei Yang, Guoshuai Zhang, Shijin Wang, Lili Shao, Lide Tian. 2021. Black carbon and dust in the Third Pole glaciers: Revaluated concentrations, mass absorption cross-sections and contributions to glacier ablation. Science of the Total Environment, 789: 147746. https://doi.org/10.1016/j.scitotenv.2021.147746. Marcovecchio, A., Behrangi, A., Dong, X., Xi, B., Huang, Y. Precipitation Influence on and Response to Early and Late Arctic Sea Ice Melt Onset During Melt Season. International Journal of Climatology 
Mayer C, Lambrecht A, Belo ` M, Smiraglia C and Diolaiuti G.: Glaciological characteristics of the ablation zone of Baltoro glacier, Karakoram, Pakistan. Ann. Glaciol., 43, 123-131, doi: 10.3189/172756406781812087, 2006

Niu, H., Kang, S., Wang, H., Du, J., Pu, T., Zhang, G., Lu, X., Yan, X., Wang, S., Shi, X., 2020. Light-absorbing impurities accelerating glacial melting in southeastern Tibetan Plateau. Environ. Poll. 257, 113541. https://doi.org/10.1016/j.envpol.2019.113541.

Rai M., Mahapatra P.S., Gul C. et al., Aerosol Radiative Forcing Estimation over a Remote High-altitude Location ( 4900 masl) near Yala Glacier, Nepal, jurnal of Aerosol and Air Quality Research, 19: 1872-1891, doi: 10.4209/aaqr.2018.09.0342, 2019

Pepin N C and Lundquist J D 2008 Temperature trends at high elevations: patterns across the globe Geophys. Res. Lett. 35 L14701

Qian, Y., Flanner, M. G., Leung, L. R. and Wang, W. 2011. Sensitivity studies on the impacts of Tibetan Plateau snowpack pollution on the Asian hydrological cycle and monsoon climate. Atmos. Chem. Phys. 11, 1929-1948.

Qu, B., Ming, J., Kang, S. C., Zhang, G. S., Li, Y. W., Li, C. D., Zhao, S. Y., Ji, Z. M. and Cao, J. J.: The decreasing albedo of the Zhadang glacier on western Nyainqentanglha and the role of light-absorbing impurities, Atmos. Chem. Phys., 14(20), 11117-11128, doi:10.5194/acp-14-11117-2014, 2014.

Quinn, P. K., Bates, T. S., Baum, E., Doubleday, N., Fiore, A. M., Flanner, M., Fridlind, A., Garrett, T. J., Koch, D., Menon, S.,Shindell, D., Stohl, A., and Warren, S. G.: Short-lived pollutants in the Arctic: their climate impact and possible mitigation strategies, Atmos. Chem. Phys., 8, 1723-1735, doi:10.5194/acp-8-1723-2008, 2008.

Ramanathan, V., and Carmichael, G.: Global and regional cli- mate changes due to black carbon, Nat. Geosci., 1, 221-227, doi:10.1038/Ngeo156, 2008.

Ricchiazzi, P., Yang, S. R., Gautier, C., and Sowle, D.: SBDART: A research and teaching software tool for planeparallel radiative transfer in the Earth's atmosphere, B. Am. Meteorol. Soc., 79, 2101-2114, 1998.

Schmale, J., Flanner, M., Kang, S., Sprenger, M., Zhang, Q., Guo, J., Li, Y., Schwikowski, M., Farinotti, D., 2017. Modulation of snow reflectance and snowmelt from Central Asian glaciers by anthropogenic black carbon. Sci. Rep. 7, 40501. https://doi.org/10. 1038/srep40501.

Vaux, H. J., Jr., Balk, D., Cook, E. R., Gleick, P., Lau, W. K.-M. et al.: Himalayan Glaciers: Climate Change, Water Resources, and Water Security. National Academies Press, Washington, DC, 2012.

Wang, X., Pu, W., Ren, Y., Zhang, X., Zhang, X., Shi, J., Jin, H., Dai, M. and Chen, Q.: Snow albedo reduction in seasonal snow due to anthropogenic dust and carbonaceous aerosols across northern China, Atmos. Chem. Phys. Discuss., (September), 1-52, doi:10.5194/acp-2016-667, 2016.

Wang, Y., Ma, P.L., Peng, J., Zhang, R., Jiang, J.H., Easter, R.C., Yung, Y.L., 2018. Constraining aging processes of black carbon in the community atmosphere model using environmental chamber measurements. J. Adv. Model. Earth Syst. 10 (10), 2514e2526. https://doi.org/10.1029/2018MS001387.

Warren, S. G., and R. E. Brandt .: Optical constants of ice from the ultraviolet to the microwave: A revised compilation, J. Geophys. Res.,113, D14220, doi:10.1029/2007JD009744, 2008.

Xu, B., Cao, J., Joswiak, D. R., Liu, X., Zhao, H. and He, J.: Post-depositional enrichment of black soot in snowpack and accelerated melting of Tibetan glaciers, Environ. Res. Lett., 7(1), 14022, doi:10.1088/1748- 
9326/7/1/014022, 2012.

Yang, S., Xu, B., Cao, J., Zender, C. S. and Wang, M.: Climate effect of black carbon aerosol in a Tibetan Plateau glacier, Atmos. Environ., 111, 71-78, doi:10.1016/j.atmosenv.2015.03.016, 2015.

Yasunari, T. J., Koster, R. D., Lau, W. K. M., and Kim, K.: Impact of snow darkening via dust, black carbon, and organic carbon on boreal spring climate in the Earth system, J. Geophys. Res.-Atmos., 120, 5485-5503, https://doi.org/10.1002/2014JD022977, 2015.

Yasunari, T. J., Bonasoni, P., Laj, P., Fujita, K., Vuillermoz, E., Marinoni, A., Cristofanelli, P., Duchi, R., Tartari, G. and Lau, K. M.: Estimated impact of black carbon deposition during pre-monsoon season from Nepal Climate Observatory - Pyramid data and snow albedo changes over Himalayan glaciers, Atmos. Chem. Phys., 10(14), 6603-6615, doi:10.5194/acp-10-6603-2010, 2010.

Yao, T., Xue, Y., Chen, D., Chen, F., Thompson, L., Cui, P., Koike, T., Lau, W. K., Lettenmaier, D., Mosbrugger, V., Zhang, R., Xu, B., Dozier, J., Gillespie, T., Gu, Y., Kang, S., Piao, S., Sugimoto, S., Ueno, K., Wang, L., Wang, W., Zhang, F., Sheng, Y., Guo, W., , Yang, X., Ma, Y., Shen, S. S. P., Su, Z., Chen, F., Liang, S., Liu, Y., Singh, V. P., Yang, K., Yang, D., Zhao, X., Qian, Y., Zhang, Y., \& Li, Q. (2019). Recent Third Pole's Rapid Warming Accompanies Cryospheric Melt and Water Cycle Intensification and Interactions between Monsoon and Environment: Multidisciplinary Approach with Observations, Modeling, and Analysis, Bulletin of the American Meteorological Society, 100(3), 423-444. Retrieved Nov 1, 2021, from https://journals.ametsoc.org/view/journals/bams/100/3/bams-d-17-0057.1.xml

You Q., Z. Cai, Nick Pepin, Deliang Chen, Bodo Ahrens, Zhihong Jiang, Fangying Wu, Shichang Kang, Ruonan Zhang, Tonghua Wu, Pengling Wang, Mingcai Li, Zhiyan Zuo, Yanhong Gao, Panmao Zhai, Yuqing Zhang. Warming amplification over the Arctic Pole and Third Pole: Trends, mechanisms and consequences. EarthScience Reviews, 217: 103625. https://doi.org/10.1016/j.earscirev.2021.103625.

Zaveri, R., Easter, R., Fast, J., and Peters, L.: Model for simulating aerosol interactions and chemistry (MOSAIC), J. Geophys. Res., 113, D13204, doi:10.1029/2007JD008782, 2008.

Zhang, Q., Kang, S., Kaspari, S., Li, C., Qin, D., Mayewski, P. A., and Hou, S.: Rare earth elements in an ice core from Mt. Everest: Seasonal variations and potential sources, Atmos. Res., 94, 300- 312, 2009.

Zhang, X. L., Wu, G. J., Kokhanovsky, A., Yao, T. D., and Tong D.: Spectral albedo parameterization for dirty snow with considering mirco-physicochemical properties of impurities - Part I: Theory and preliminary evaluation, 2016

Zhang, Y., Kang, S., Xu, M., Sprenger, M., Gao, T., Cong, Z., Li, C., Guo, J., Xu, Z., Li, Y., Li, G., Li, X., Liu, Y. and Han, H.: Light-absorbing impurities on Keqikaer Glacier in western Tien Shan : concentrations and potential impact on albedo reduction, Sciences in Cold and Arid Regions, 9(2), doi:10.3724/SP.J.1226.2017.00097. 2017.

Zhang Y. L., S. Kang, M. Sprenger, Z. Cong, T. Gao, C. Li, S. Tao, X. Li, X. Zhong, M. Xu, W. Meng, B. Neupane, X. Qin, M. Sillanpää. 2018. Black carbon and mineral dust in snow cover on the Tibetan Plateau. The Cryosphere, 12: 413-431. https://doi.org/10.5194/tc-12-413-2018. 
https://doi.org/10.5194/acp-2021-935

Preprint. Discussion started: 10 December 2021

(C) Author(s) 2021. CC BY 4.0 License.

528 H., Lu, Z., and Streets, D. G.: Simulating black carbon and dust and their radia- tive forcing in seasonal snow: a

529 case study over North China with field campaign measurements, Atmos. Chem. Phys., 14, 11475- 11491,

530 https://doi.org/10.5194/acp-14-11475-2014, 2014.

531

532 


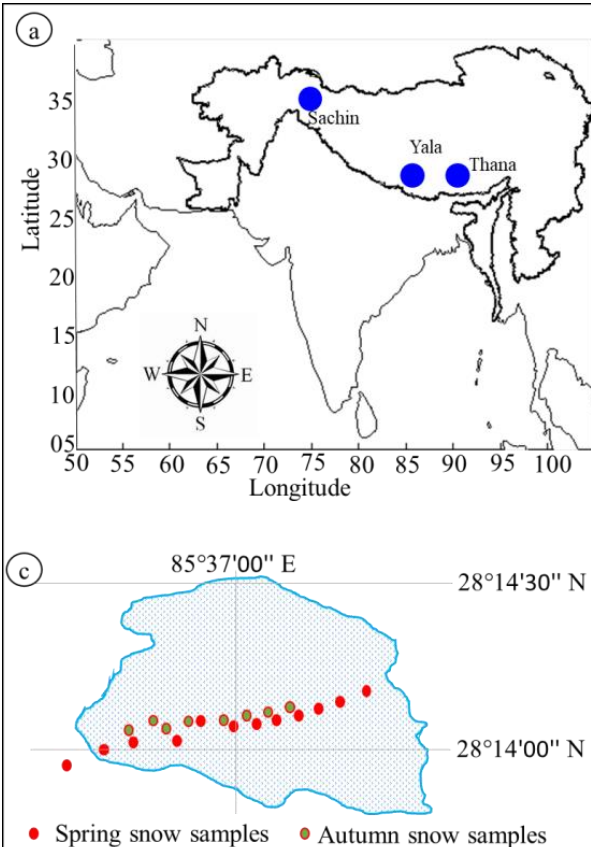

\section{(b)}

$74^{\circ} 42^{\prime} 49^{\prime \prime} \mathrm{E} \quad 74^{\circ} 45^{\prime} 35^{\prime \prime} \mathrm{E} \quad 74^{\circ} 47^{\prime} 23^{\prime \prime} \mathrm{E}$

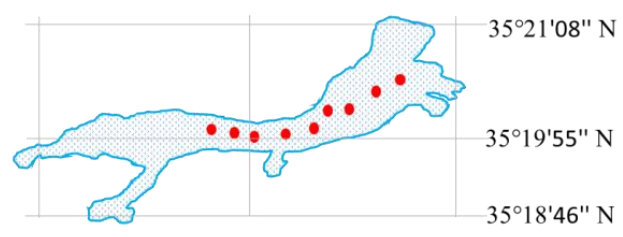

- Spring snow samples

(d) $90^{\circ} 35^{\prime} 15^{\prime \prime} \mathrm{E} 90^{\circ} 36^{\prime} 15^{\prime \prime} \mathrm{E} \quad 90^{\circ} 37^{\prime} 0^{\prime \prime} \mathrm{E}$

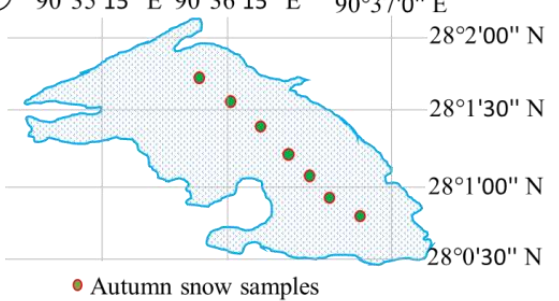

Fig. 1. Study area map (a) locations of selected glaciers in Himalaya Karakoram and Hindu Kush region (b) Sachin glacier in Pakistan (c) Yala glacier in Nepal (d) Thana glacier in Bhutan

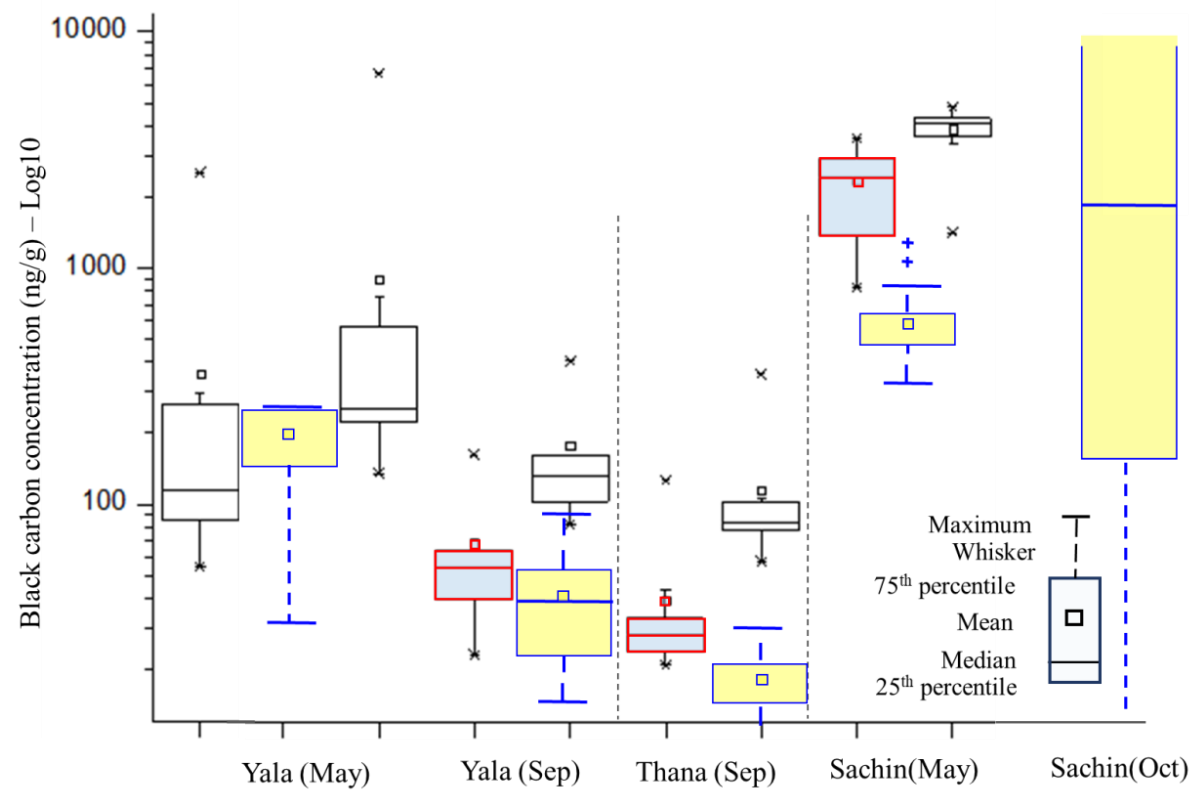

Fig. 2. Whisker plots of black carbon (red box) and organic carbon (black box) concentrations (ng/g) in snow samples collected from three different glaciers in spring and autumn 2016. The yellow boxes are representing BC content in surface snow from WRF-Chem simulations. 


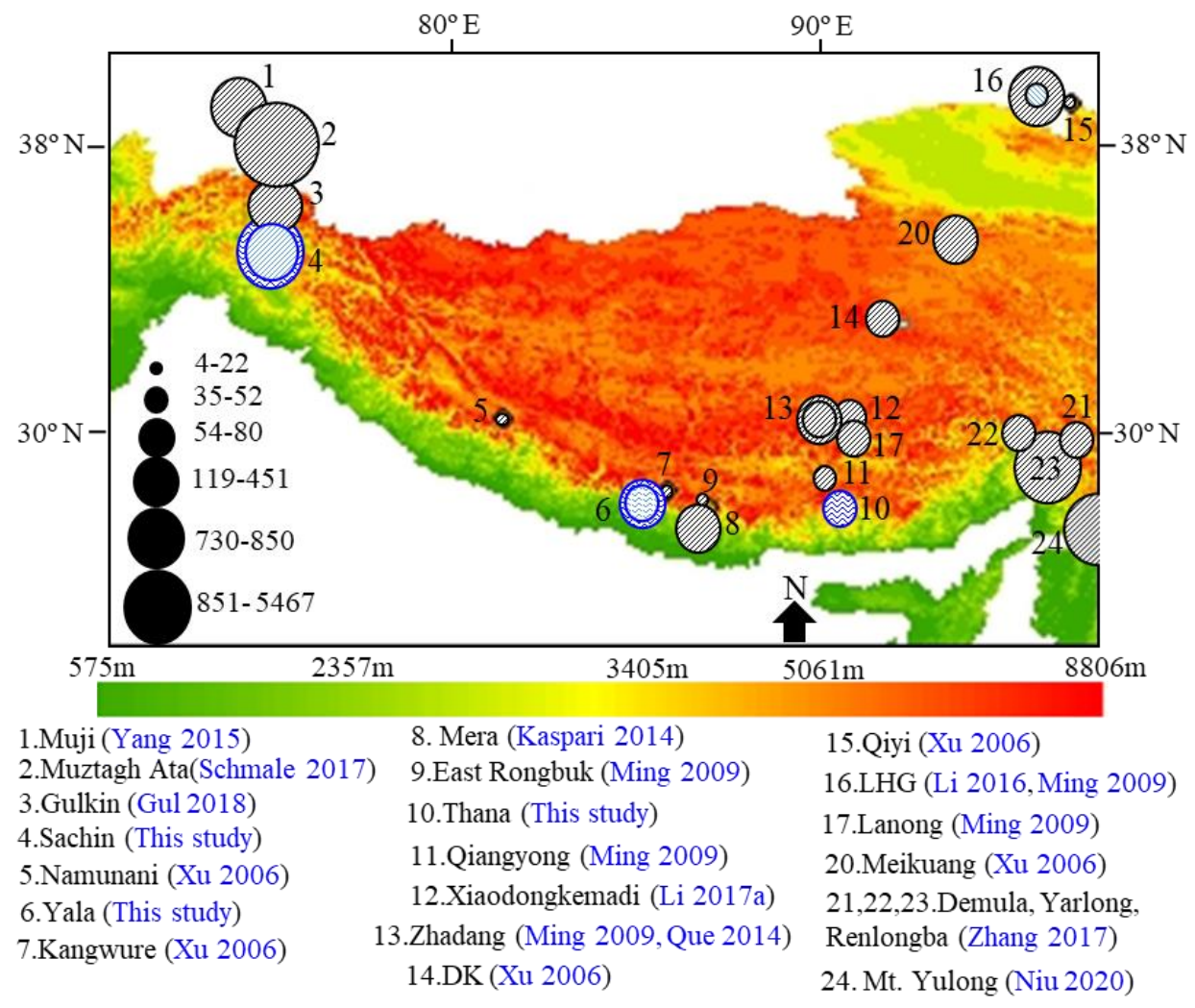

Fig. 3. Black carbon concentrations (ng/g) in snow/ice samples in Himalayan, Karakoram and Tibetan Plateau in previous studies (black circles) and this study (blue circles). 


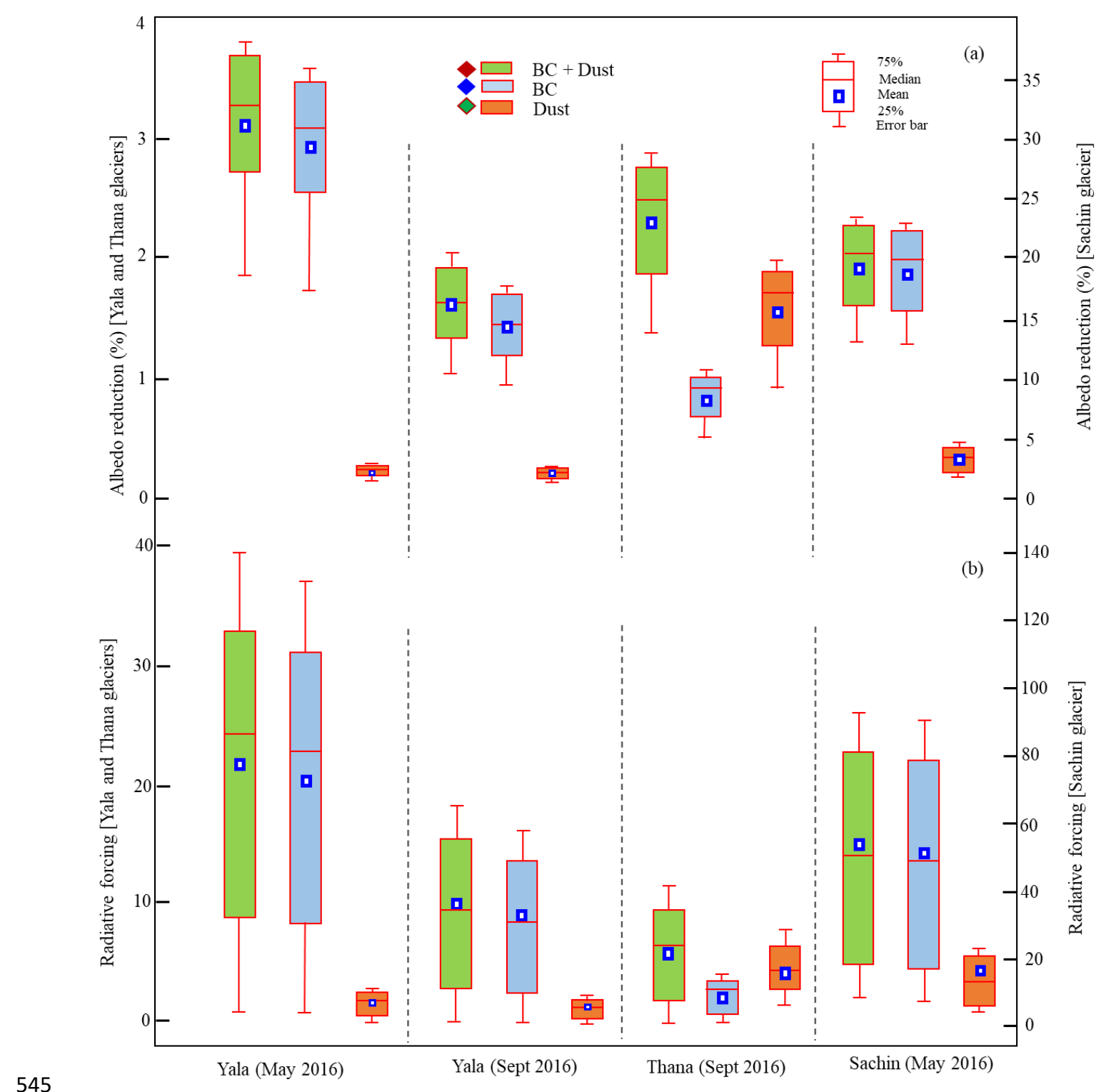

Fig. 4. (a) Snow albedo reduction due to black carbon, dust and combined (black carbon and dust) during day time for a time. 


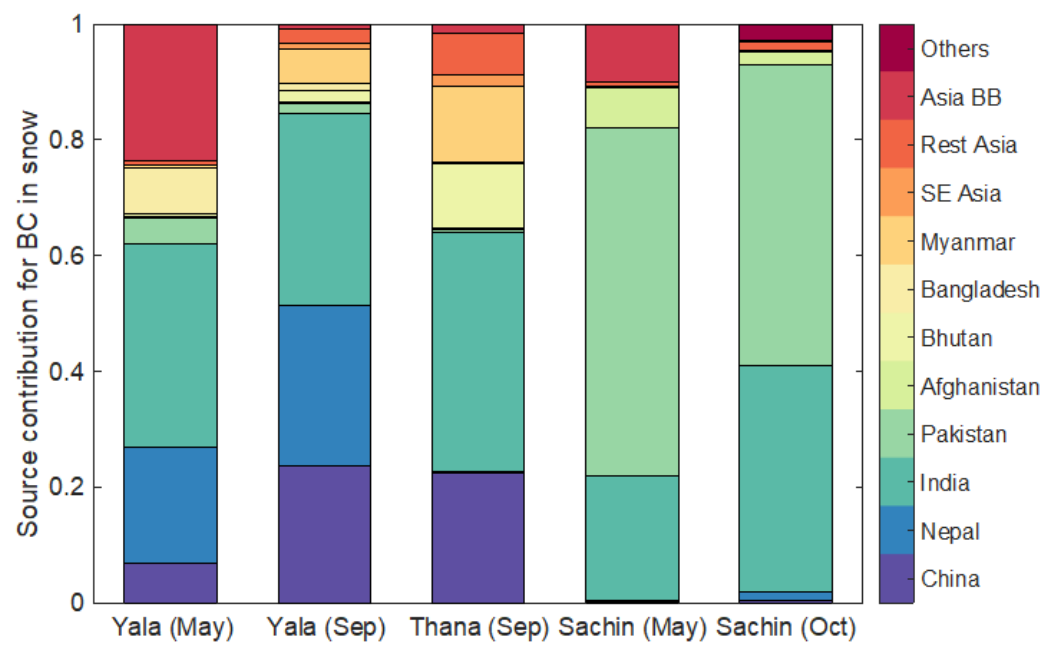

Fig. 5. Source contributions to BC content in surface snow from WRF-Chem simulations at the three measurement glacier sites during the measurement periods. Source regions include anthropogenic emissions from China, India, Nepal, Pakistan, Afghanistan, Bhutan, Bangladesh, Myanmar, Southeast (SE) Asia, and the rest of Asia, as well as Asian biomass burning (BB) and BC transported from areas outside the study domain (Others).

\begin{tabular}{|c|c|c|c|c|}
\hline Glacier & Lat/Long & Sampling date & Average elevation & Himalayas \\
\hline Yala (Nepal) & $28^{\circ} 14^{\prime} 12.25^{\prime \prime N}, 85^{\circ} 37^{\prime} 04.24^{\prime \prime E}$ & $4^{\text {th }}-7^{\text {th }}$ May 2016 & 4950 meters & Central \\
\hline Yala (Nepal) & $28^{\circ} 14^{\prime} 12.25 " \mathrm{~N}, 85^{\circ} 37^{\prime} 04.24^{\prime \prime} \mathrm{E}$ & $29^{\text {th }}$ September 2016 & 4950 meters & Central \\
\hline Thana (Bhutan) & $28^{\circ} 01^{\prime} 22.23 " \mathrm{~N}, 90^{\circ} 36^{\prime} 28.72^{\prime \prime} \mathrm{E}$ & $15^{\text {th }}$ September 2016 & 5400 meters & Central \\
\hline Sachin (Pakistan) & $35^{\circ} 19^{\prime} 55^{\prime \prime} \mathrm{N}, 74^{\circ} 45^{\prime} 35^{\prime \prime} \mathrm{E}$ & $15^{\text {th }}$ May 2016 & 3230 meters & Western \\
\hline
\end{tabular}

Table 2. Comparison of $\mathrm{BC}$ mass concentration, albedo reduction, radiative forcing and potential source regions of pollutants for central and western Himalayan glaciers during the study period

\begin{tabular}{lc|cc}
\hline & $\begin{array}{c}\text { Central Himalaya } \\
\text { min }- \text { max (average) }\end{array}$ & $\begin{array}{c}\text { Western Himalaya } \\
\text { min }- \text { max (average) }\end{array}$ & Time period \\
\hline $\begin{array}{l}\text { Monthly mean temperature } \\
\left({ }^{\circ} \mathrm{C}\right)\end{array}$ & $\begin{array}{l}2.05-14.36(10.35) \text { Yala } \\
-9.11-5.68(0.23) \text { Thana }\end{array}$ & $-10.78-14.63(3.57)$ Sachin & $\begin{array}{l}\text { Apr 2015- } \\
\text { Oct 2017 }\end{array}$ \\
$\begin{array}{l}\text { Monthly mean precipitation } \\
\left(\mathrm{mm} \text { day }^{-1}\right)\end{array}$ & $\begin{array}{l}0.04536-41.472 \text { Yala } \\
1.0195-50.112 \text { Thana }\end{array}$ & $0.1546-5.866$ (Sachin) & $\begin{array}{c}\text { Apr 2015- } \\
\text { Oct 2017 }\end{array}$ \\
$\begin{array}{l}\text { Elevation of sampling location } \\
\text { (meters) }\end{array}$ & $4580-5675(5127)$ & $3134-3957(3545)$ & 2016 \\
$\begin{array}{l}\text { Observed BC in surface snow } \\
\left(\text { ng g }{ }^{-1}\right)\end{array}$ & $21-2529(\sim 350)$ & $835-3545(\sim 2300)$ & 2016 \\
$\begin{array}{l}\text { Albedo reduction }(\%) \text { due to } \\
\text { BC particles in snow }\end{array}$ & $0.13-3.82$ & $12.00-24.00$ & 2016 \\
Instantaneous radiative forcing & $0.0-39.65$ & 0.03 to 96.48 &
\end{tabular}


https://doi.org/10.5194/acp-2021-935

Preprint. Discussion started: 10 December 2021

(c) Author(s) 2021. CC BY 4.0 License.

( $\mathrm{W} \mathrm{m}^{-2}$ ) due to $\mathrm{BC}$ particles

Potential source regions of pollutants

3. WRF-Chem simulations

For the Yala site, it is dominated $(>50 \%)$

by anthropogenic emissions from India

and Nepal for both May and October,

while the biomass burning contribution

(>20\%) increases largely in May.

For the Thana site, it is dominated $(>60 \%)$

by anthropogenic emissions from China

and India in September, while

anthropogenic emissions from Bhutan and

Myanmar also contribute about $10 \%$,
For the Sachin site, it is predominantly affected

by anthropogenic emissions from India and

Pakistan (total contribution $>80 \%$ ), while the

spring biomass burning only contributes to

$\sim 10 \%$ in May. 